\title{
Importance and expansion of the Islamic Bank Sector
}

\author{
Dr. Gyöngyi Bánkuti (Hungarian University of Agriculture and Life Sciences, Hungary)
}

\begin{abstract}
Islamic Finance grows in international finance across the globe. The aim of this study is to introduce the importance and specificities of the rapidly expanding Islamic banking system worldwide, as well as its expansion process. After a summary of the economic principles of the Islamic banking systems, with special emphasis on the principle of profit and risk sharing, - which essentially distinguishes Islamic and traditional interest-based banking systems - special highlight will be on the countercyclical feature of Islamic banks, which is also a fundamental difference from the procyclical feature of the traditional banking systems. The spread of the Islamic banking system is investigated, also stated, that the growth of it can be only partly explained by the expansion of the Muslim population. It can be stated, the Islamic banking system will become a decisive factor that will gain more portion of the financial market, mostly in some specific regions, but also worldwide - especially considering only the distribution of non-speculative transactions is concluded.
\end{abstract}

\section{Introduction}

Islamic Banking System (IBS) started about fifty years ago and become an economic tool/instrument in the 1970s. The first bank was founded in Dubai in 1975. Interest-free banking has increasingly been common in many other countries like THE USA and UK. (Karapinar and Dogan, 2015) After the outbreak of the crises in 2008, there occurred more focus is on interest-free banks. These banks have not got such 'toxic' assets as traditional banks, and they offered safer operations. Conventional banks have started operating Islamic departments, these sections are called "Islamic windows". (Varga and Tálos, 2016)

Our study aims to examine the Islamic banking system worldwide, with a special highlight on profit and risk sharing, as this is the most significant difference between conventional and Islamic banking systems, also the anticyclical feature of the Islamic banking system, is also a major difference from the procyclical feature of the conventional banking system.

The list of questions and hypotheses were examined.

- Whether the growth of Islamic finance can be explained only by the expansion of the Muslim population?

- Whether MENA (Middle East Nort Africa) is the best financially developed region of the world?

- What is the share of Islamic transactions in the world total (option: considering only the non-speculative transactions) and how has this evolved?

- Whether Islamic banking services might be attractive for the non-muslim population?

We will try to confirm, that the Islamic banking system takes a significant part in the financial institution system of the world. Also, that it plays and will play a fundamental factor, especially, if only the distribution of the nonspeculative transactions is considered.

\section{Principles of the Islamic banking system}

The philosophy of Islamic financing derives from the principle of sharing the risk, not from transferring the risk. Risk is the major mainspring of profit or loss, since risk is shared, therefore both profit and loss must be shared. Common risk leads to a common economy, and this will certainly be important for the stability and prosperity of the economy. (Hafez and Halim, 2019) The demand for Islamic financial products has increased, which represents this philosophy. (Tálos, et. al, 2016)

According to the revised IFSB Compilation guide (2019) there are three following types of IIFSI (Institutions Offering Islamic Financial Services) structure which can be distinguished worldwide:

a) Dual system: the co-existence of conventional and Islamic financial services, with the latter provided by both full-fledged IIFS and "Islamic window" operations at conventional financial institutions - e.g. in Malaysia and Indonesia.

b) Dual system with a separation between the conventional system and the Islamic system: non-existence of "Islamic windows", since only full-fledged IIFS are allowed to offer Shariah-compliant products and services in a country - e.g. in Bahrain and Jordan.

c) Full Islamisation of the financial system: absence of conventional financial institutions, since only full-fledged IIFS are licensed to operate in a country - e.g. in Iran and, until recently, Sudan.

These three types are not new, not regulated by this revised compilation guide but the previous version of it. Islamic financial products are available to customers regardless of religion, ethnicity, or belief even in numerous non-Islamic countries. In Malaysia, for example, 52\% of the Islamic banks' customers are non-Muslim (Tabash, 2017). 
Islamic banks operate without the typical practice of charging interest but using a participation system. They operate according to Islamic principles, which means that they do not have such "toxic" assets as traditional banks, furthermore their loans are not converted into securities, and do not undertake high-risk or speculative transactions. As soon as the attention was focused on interest-free banking, or, as the world calls them, Islamic banks, several conventional banks have started to operate such departments. These sections are called 'Islamic windows'. (Gálosi, 2010), (Tálos et al., 2016).

The reason why Islamic finance (interest free banking or participation banking) operate safer are the following.

The financial system based on divine principles sourced from Muslims holy book "Holy Quran" and Sunnah. (Tabash, 2017) According to Islam, the money is just a simple instrument and it has no value by itself, it is merely used to measure the value of things. The principles of Islamic finance are derived from the Qur'an and the Sunnah. Both the resources dictate that paying interest is prohibited (Said and Ali, 2016).

After the crisis in 2008, the demand for Islamic financial products increased. (Tálos, et. al, 2016) These banks operate according to Islamic principles and emphasize partnership and cooperation. Risk and profit are shared among investors based on a pre-agreed ratio. (Tabash, 2017) The Islamic financial system, institutions, firms, and tools base their operations on interest-free transactions and profit and loss sharing. Accordingly, all participants share the risk, profit, and loss (Alzoubi, 2018). The idea of interest-free banking was enforced only in the 1950's. (Karapinar and Dogan, 2015)

Islamic banks operate in a way that is significantly different from conventional banks (Alzoubi, 2018). Alzoubi (2018) shows that most Islamic finance tools have existed and been used even before Islam. Islamic banks as independent financial institutions began to operate in the 1970's. Islamic finance industry incepted since 1963 from Egypt, and formally incorporated in 1974 by establishment of a full-fledge Islamic bank in UAE. (Masood, et. al, 2016)

Tabash and Dhankar (2014) pointed to the double importance of Islamic banks, which comes from the remarkable growth and stability during the crises. Islamic banking system became more and more important in the recent decade. Islamic finance products are available for all people irrespective of their religions, race, and beliefs. In Malaysia, for example, 52\% of Islamic banks' customers are non-Muslims, which means that people can have access to Islamic banking products around the world. (Tabash, 2017)

\section{The growth Muslim Population - as a possible reason of the expansion of the Islamic Finance}

The importance of the Islamic Banking System has been getting more and more considerable in the recent decade. One reason for it might be the increase of the Islamic population worldwide. (Figure 1.)

\section{Muslim population and percentage wordwide}

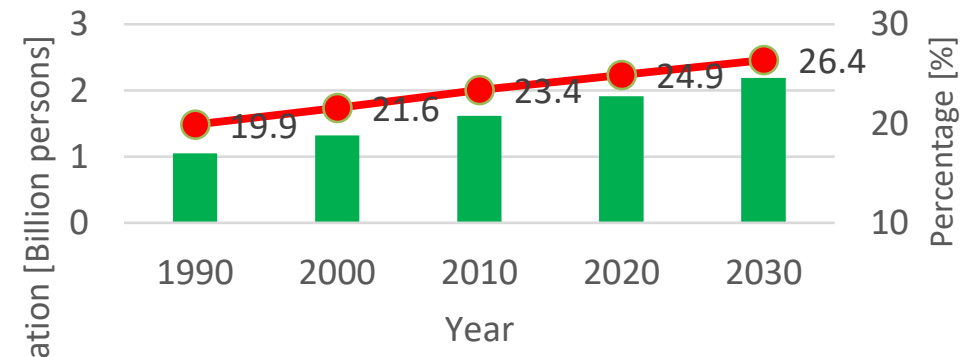

Muslim population worldwide [Billion persons]

-Percentage of the world's population

Figure 1. Population and rate of Islamic people in the world Source: Own compilation based on (Strüning, 2011); (Kettani, 2014)

Islam is currently the world's second-largest religion after Christianity, but it will be the fatest-growing religious group in the coming decades. Figure 2. shows the different growth of major religions. Christianity, with its $34 \%$ growth rate, reaches an average level, while $70 \%$ of Muslim growth is far above average. (Lipka, 2017) 


\section{Muslims projected to be fastest- growing major religious group}

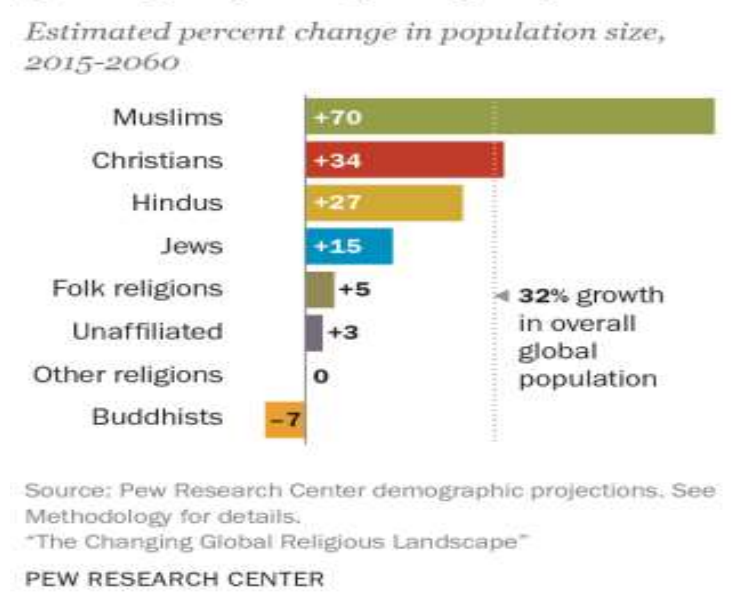

Figure 2. The growth of the religion groups between 2015-2060 Source: (Lipka, 2017)

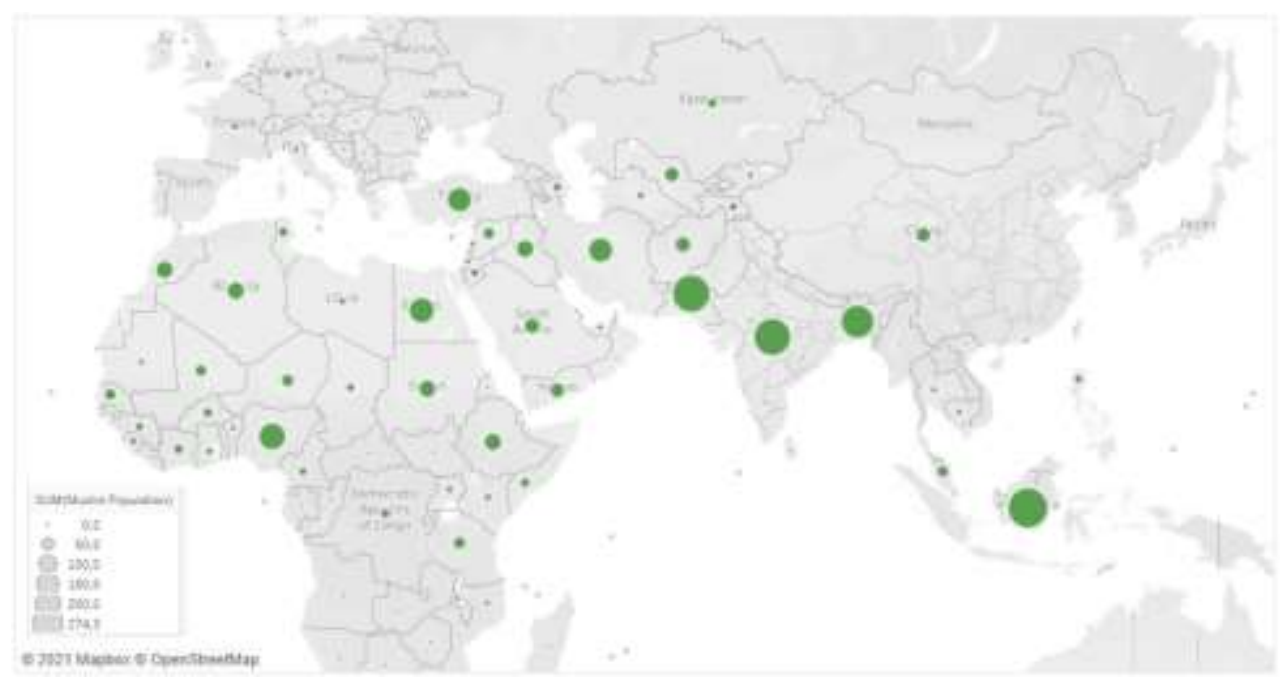

Figure 3. Muslim population in 2021 Source: Own compilation based on World Population Review

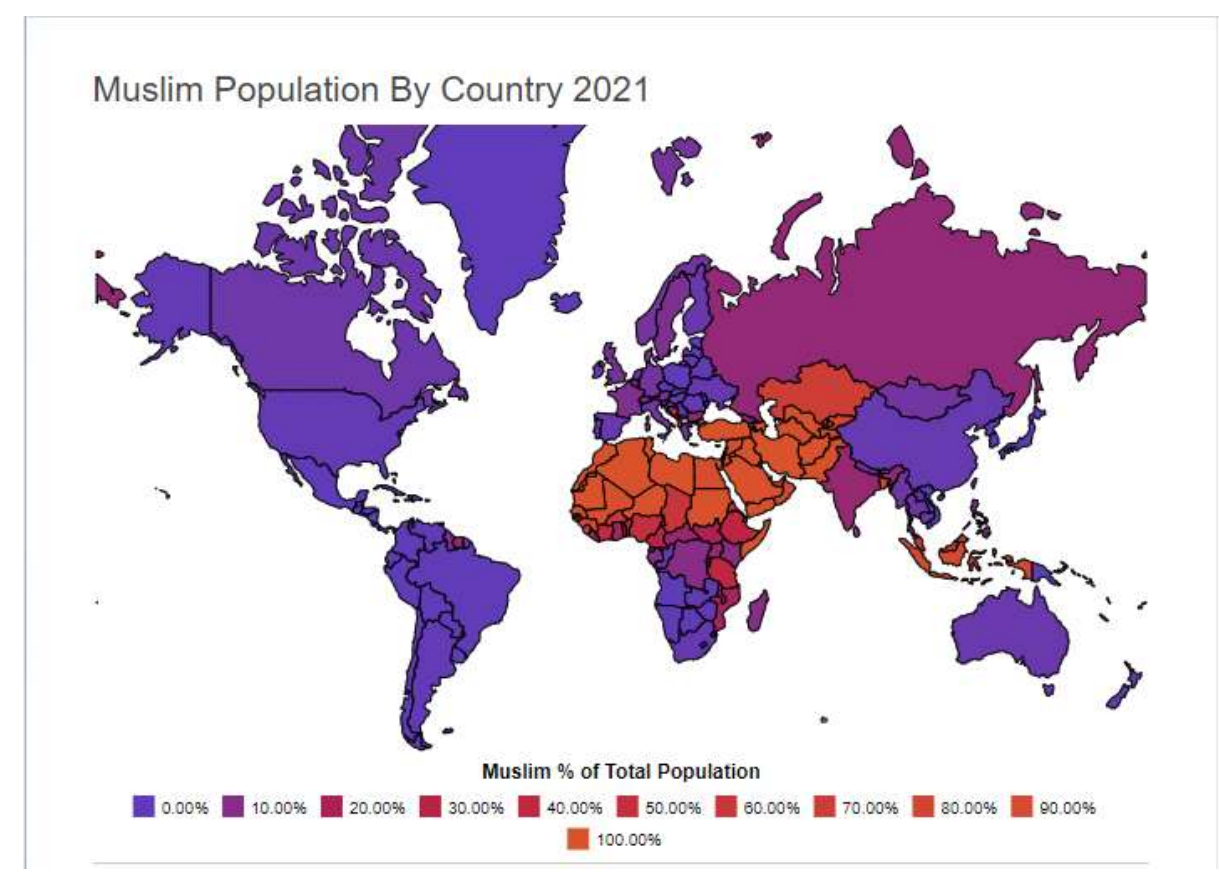

Figure 4. Muslim population percentage by countries, Source: World Population Review 
Based on the summing up of PEW Research Centre (Desilver and Masci, 2017), two-thirds of the Muslims lives in South Asia. More Muslim lives in India and Pakistan (344 million) than in North-Africa and Near-East together (317 million). The largest Islamic religious population of the world (274 million) lives in India the second one (233 million) in Indonesia (Worldometer, World Population by Religion 2021.) (Figure 3.)

A large number of the Muslim population lives in various parts of the world. They do not form a homogenous group. The main difference among these groups is, which branch of Islam they follow (Shia, Sunni, Wahhabi, or Sufi) and how strictly they follow the rules of their religion. Therefore, we cannot speak about a uniform Muslim society.

Figure 4. shows the spatial distribution of the Muslim population, considering the percentage of the inhabitants in the counties. It shows the most Muslim countries are in the Middle East, North Africa (MENA) region even now. That is why the Islamic banking system will become a decisive factor in this region.

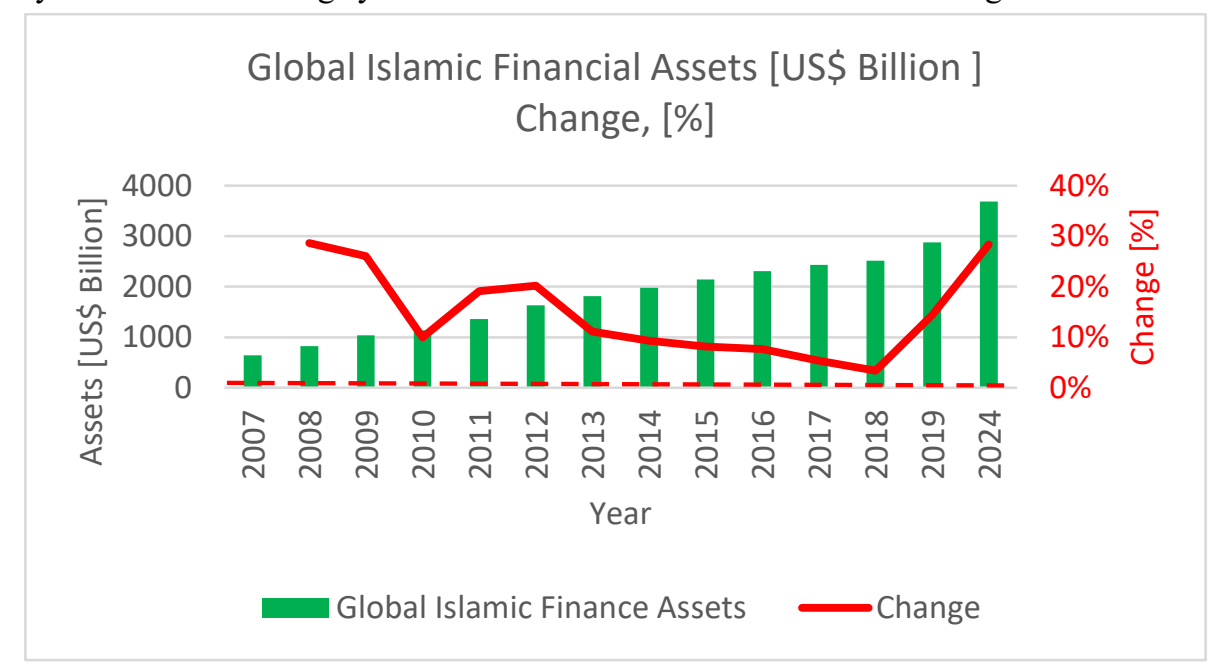

Figure 5. Global Islamic Finance Assets 2007 - 2019 Source: ICD-Refinitiv IFDI Report 2020

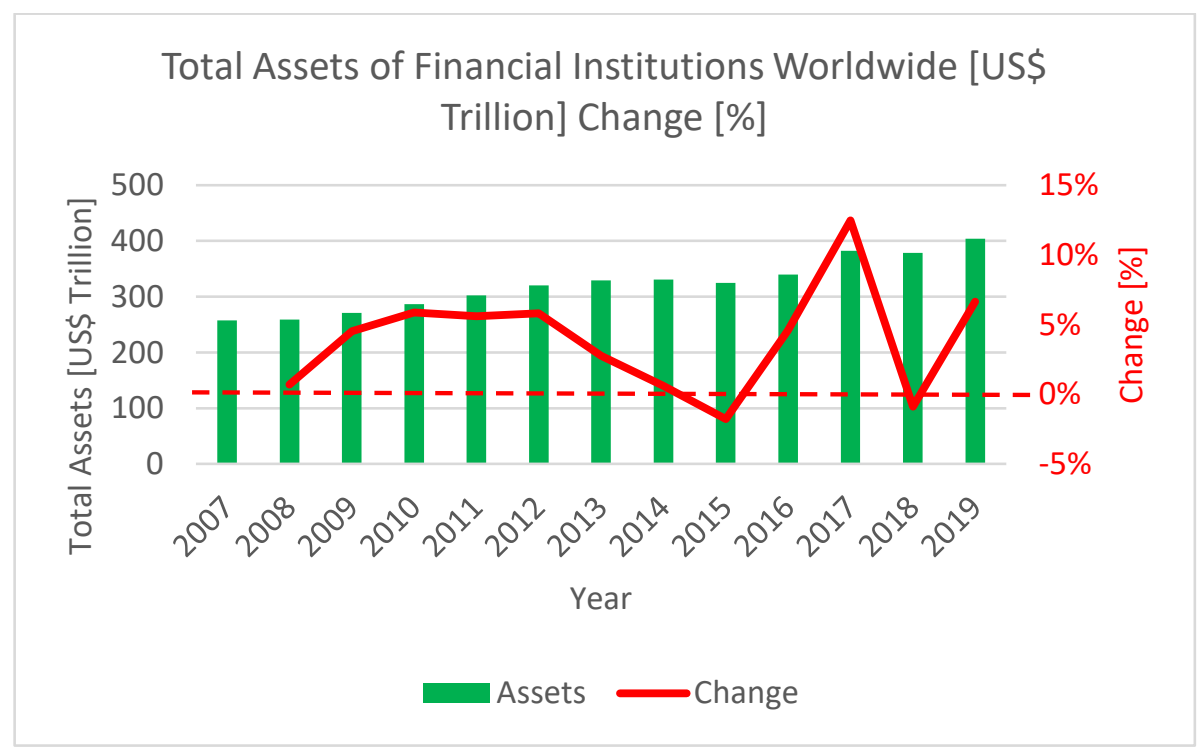

Figure 6. Total Assets of Financial Institutions 2007 - 2019 Source: (Norrestad, 2021)

\section{The worldwide expansion of the Islamic banking system}

The future for the growth of Islamic finance looks bright. Nonetheless, there are several Critical Impeding Factors (CIFs) affecting its growth, which affects the Islamic microfinance industry as well. (Tabash, 2017) Islamic banking and finance have reached a successful and unprecedented expansion among Muslims all over the world during the last few years. Islamic banking and finance or Shariah bank grow very significantly throughout the world both in the countries with a majority Muslim population and in western countries with a majority nonMuslim population. (Said and Ali, 2016) 
The global Islamic Financial Assets were dynamically growing recently. (Figure 5.) The amount in 2019 reached 4,5 times value of the baseline value in 2007 . The change is not constant, but there is no negative $\%$ in the growth. (See the rightside axis with red titles, values.) Figure 5. contains the estimated value for 2024 as well.

The fact, that International Monetary Fund (IMF) also investigated the share of the Islamic Financial Assets, also proves the importance of this issue in the financial world. In th IMF study, they describe appreciatively about the performance of this sector: „Islamic banking (IB) continues to grow rapidly, in size and complexity, posing a challenge to supervisory authorities and central banks." (IMF 2017)

On Figure 6. the graph about the Total Financial Assets from 2007, till 2019 can be seen. The right ax is shows the change in [\%], that was at even negative at crises time. This is a difference compared with the Islamic assets, as on the $\left(5^{\text {th }}\right)$ diagram there is no negative $\%$ value.

\begin{tabular}{|c|c|c|c|c|c|c|c|c|c|c|c|}
\hline Indicators & Currency & Unit & $\begin{array}{c}2013 \\
\text { Q4 }\end{array}$ & $\begin{array}{c}2014 \\
\text { Q4 }\end{array}$ & $\begin{array}{l}2015 \\
\text { Q4 }\end{array}$ & $\begin{array}{c}2016 \\
\text { Q2 }\end{array}$ & $\begin{array}{c}2017 \\
\text { Q4 }\end{array}$ & $\begin{array}{c}2018 \\
\text { Q1 }\end{array}$ & $\begin{array}{c}2018 \\
\text { Q2 }\end{array}$ & $\begin{array}{c}2018 \\
\text { Q3 }\end{array}$ & $\begin{array}{c}2018 \\
\text { Q4 } \\
\end{array}$ \\
\hline Total assets & USD & $\mathrm{B}$ & 1168 & 1282 & 1332 & 1531 & 1684 & 1700 & 1652 & 1692 & 1754 \\
\hline $\begin{array}{l}\text { Total Shariah- } \\
\text { compliant } \\
\text { financing }\end{array}$ & USD & B & 753 & 810 & 854 & 937 & 1021 & 1033 & 1013 & 1028 & 1052 \\
\hline \begin{tabular}{|l|} 
Total \\
funding/liabilities
\end{tabular} & USD & B & 1067 & 1181 & 1239 & 1476 & 1626 & 1642 & 1655 & 1689 & 1748 \\
\hline \begin{tabular}{|l} 
Number of \\
Islamic banks
\end{tabular} & n.a. & G & 169 & 171 & 175 & 182 & 190 & 190 & 191 & 189 & 189 \\
\hline $\begin{array}{l}\text { Number of } \\
\text { Islamic banking } \\
\text { windows }\end{array}$ & n.a. & G & 83 & 85 & 85 & 83 & 83 & 83 & 82 & 81 & 81 \\
\hline $\begin{array}{l}\text { Number of } \\
\text { branches in } \\
\text { Islamic banks }\end{array}$ & n.a. & $\mathrm{T}$ & 29 & 29 & 30 & 30 & 30 & 30 & 30 & 29 & 30 \\
\hline $\begin{array}{l}\text { Number of } \\
\text { employees in } \\
\text { Islamic banks }\end{array}$ & n.a. & $\mathrm{T}$ & 350 & 365 & 390 & 387 & 389 & 390 & 395 & 391 & 391 \\
\hline
\end{tabular}

Note: $\mathrm{T}$ - thousand, G - general number, B - billions, USD - US dollars, n.a. - not applicable.

The aggregated data for total assets (21 countries), total Shariah-compliant financing (19 countries), and total funding/liabilities (19 countries) are calculated from available countrywide structural data from Islamic banks and Islamic banking windows of conventional banks, converting into U.S dollar terms, at the end period exchange rates.

Table 1. Main selected data of the Islamic banking sectors Source: Islamic Finance Service Board (ifsb) Database

From Table 1. the continuous growth of Islamic banking system is clearly visible, based on the statistics of the selected financial indicators for the time period of 2013-2018. The size of the banking system in finance is traditionally measured by total assets. This is the measure of growth, which increased by $50.2 \%$ in nominal terms over this period.

Because of lack of data about the muslim population not easy to prove that Islamic Financial Assets were growing at a higher rate than the population. The reason of lack of population data is, that muslims are living in several countries as majority and also minority. There is no census in every year, in every country and no platform where the data are collected yearly. Thus, there can be only estimations and decennial data, (Strüning, 2011); (Kettani, 2014) see Figure 1. In $201021.6 \%$ of the world's population were muslims. This year $3.97 \%$ of the Financial Assets of the world belonged to Islamic Finance. In 2020 the muslim population growed to form $24.9 \%$ of the world's population. The proportional growing in Finantial Assets would result $4.57 \%$ of the world's Financial Assets. Altought, the Islamic Financial Assets has reached $7.11 \%$ even in 2019, that's one and a half times much as population growth would justify! (Remark: The Islamic financial usage of non-Muslims does not affect this line of thinking, as its growth cannot be of this (1.5 times) magnitude. This reasoning proves the Islamic Financial Assets are growing much more faster than the population rate.

Islamic banking takes place in more than 80 countries, the distribution of them and the ranking can be visualized on a map. (Figure 7.) 


\section{ISLAMIC FINANCE DEVELOPMENT INDICATOR 2020}

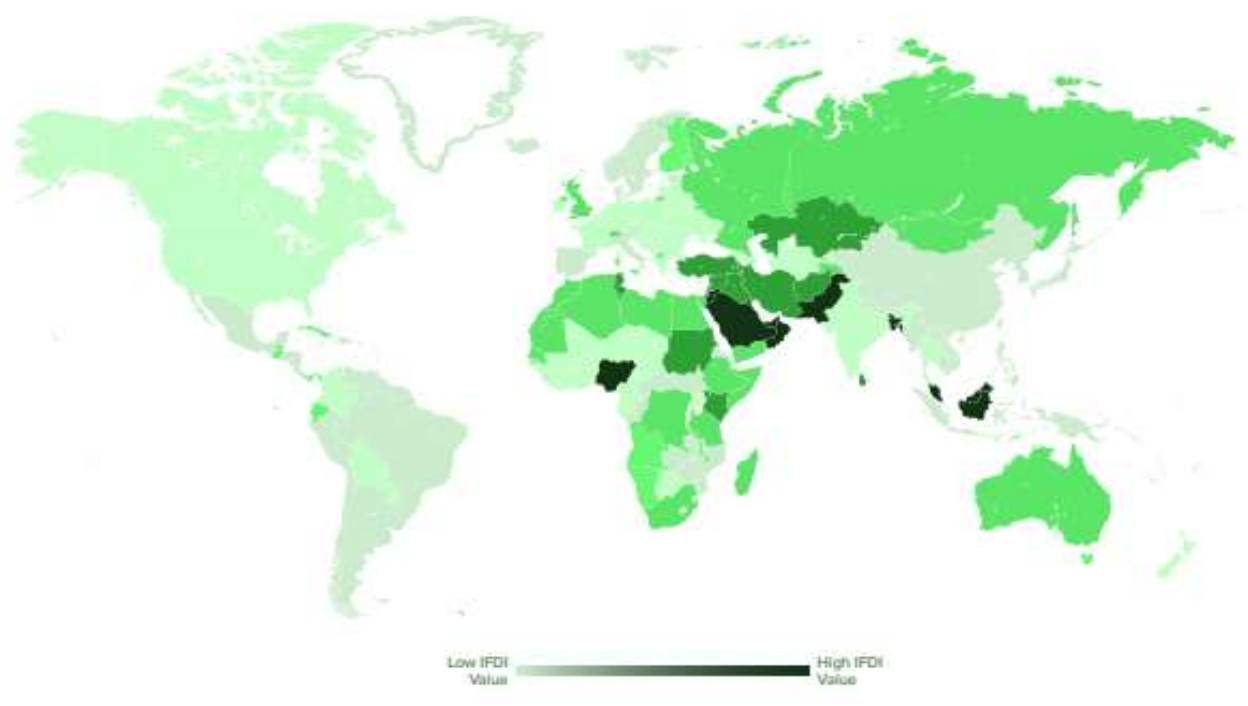

MOST DEVELOPED COUNTRIES IN ISLAMIC FINANCE

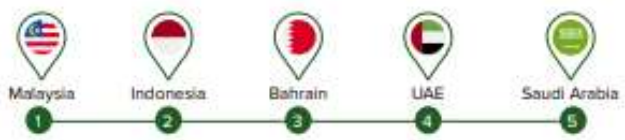

Figure 7. Islamic Finance Development Indicator worldwide in 2020. Source: ICD-Refinitiv IFDI Report 2020

The map on (Figure 7.) provides information about Islamic Banks has and also will certainly have significant role in the regions and countries of MENA (Middle East North Africa) region, but not only there, as Malaysia, Indonesia, Pakistan and also in Nigeria are the most developed countries at this field.

\section{The procyclical-anticyclical feature of the banking systems and the speculative transactions}

The procyclical feature of the banking systems and the rate of speculative transactions were also investigated. In case of payment difficulties conventional banks tend to strict, i.e. they deepen the crisis. (Varga, 2012) Procyclicality refers to short-term prosperity economic cycle moves along with the banks' lending activity, tight of credit ratings, and advancement of profitability. In the increasing cycle, banks lend even with lower collateral, create fewer provisions, and are overly optimistic about their customers' situation. However, in case of unfavourable economic environment circumstances, banks restrain their lending activity and a high provision burden falls on them, which led to the detriment of profitability. In a declining cycle, the banking sector contributes to deepening the economic downturn. This pro-cyclical behaviour is a very detrimental factor of financial stability. (Horváth, et. al, 2002)

When the financial system moves along with the real economy system, this process is called procyclical. In times of downturn, even businesses that would otherwise be able to finance without problems may not receive credit, i.e. the crisis deepens. During prosperity the exact opposite process takes place. This phenomenon can be explained by the fact that banks have different risk tendencies in different periods concerning the economic cycle, thus, they tend to overreact to different cycles. Procyclicality is not only influenced by the expectations of the development of the economic cycle but also it is influenced by the development of profitability. Incomes of the banks increase implicitly, while in times of decline incomes decrease. In this case, reserves play a role. Reserves are reduced during prosperity, while during downturns they are greatly increased. There is a strong negative correlation between the ratio of economic cycles and provisions. Procyclical behaviour also has an impact on financial crises, and several studies consider it as a crisis indicator, therefore different solutions have been invented to retrieve procyclicality (Horváth, et. al, 2002).

There are no speculative transactions in Islamic Finance. The main reason for it is, Sharia's regulation, which is checked by the Shariah Supervisory Boards. The second reason is the time and the expenses of the transactions. Some publication states speculative transactions are very frequent in conventional banks. Lietaer and co-authors claim: „In 2010, the volume of foreign exchange transactions reached \$4 trillion per day. One day's exports or imports of all goods and services in the world amount to about $2 \%$ of that volume. Thus, $98 \%$ of transactions on 
these markets are purely speculative (Lietaer et al., 2015). If we assume this statement, we get a much higher rate for the rate of Islamic per all transactions. It becomes about 35\%, instead of $7.11 \%$, were calculated for 2019.

\section{Conclusion}

After introducing the main features of the Islamic banking system, this study aimed to examine the details of the worldwide expansion process.

The investigation of the question, whether the spread of the Islamic banking system can be explained only by the expansion of the Muslim population was not easy because of lack of data. The solution came by comparing the proportion of the Muslim population and the proportion of the Islamic Financial Assets rate of the worldwide ones - unfortunately, based on sparse data. There were concluded, the spread of the Islamic banking system can not be explained only by the growth of the Muslim population as the growing rate of the Assets is much higher than the growth rate of the population

The geographic situation of Islamic Finance could be investigated based on Islamic Finance Development Indicator. This investigation showed - contrary to popular belief - not exclusively the Middle East North African (MENA) region is well developed. Not these countries are the most developed, but Malaysia, Indonesia, Pakistan, and Nigeria have a high ranking in this field. They might become pillars of the increasing share of the total activity and process of becoming a determining factor of the Islamic banking system in the financial world.

The countercyclical feature of Islamic banks makes an advantage for them and helps them to gain more portion of the financial market worldwide - especially considering only the distribution of non-speculative transactions.

The rate of Islamic per all transactions has been also calculated - only for the year of 2019 - considering the common statement about the rate of speculative transactions $(98 \%)$.

Thus, the share of Islamic transactions became $35 \%$, instead of the low rate of $7.11 \%$ - refers to the case that does not exclude speculative transactions.

Undoubtedly, the Shariah rules cause the practice of profit and risk-sharing, asset-backed financing, the prohibition of the collection and payment of interest by lenders and investors, prohibition of trading of monetary papers - as the money itself has no intrinsic utility. Furthermore, these cause the countercyclical nature of the Islamic banking system. All these fundamental differences are advantages compared with the traditional interestbased banking system. Thus, the Islamic banking system can make its services attractive for the nonmuslim population as well - thus, the growth of it might be even more dynamic in the near future, but some problems lack of publicity, misconceptions, prejudices, aloofness, resistance - might hinder this process. Our publication tries to support this process, by providing publicity and enhancing the reputation of Islamic Finance.

\section{References}

- Alzoubi, 2018. "Determinants of bank profitability: Islamic versus conventional banks". Banks and Bank Systems, 13 (3), pp.106-113. doi:10.21511/bbs.13 (3) 2018.10

- Gálosi, 2010. ’Iszlám ablak - ablak az iszlámra. Miképp nyújthat egy magyar bank vallásilag elfogadott szolgáltatást a hazánkban élő muszlimok számára?” BCE szakdolgozat (manuscript)

- Hafez and Halim, 2019. The efficiency of Islamic banks versus conventional banks: An empirical study of an emerging economy. Banks and Bank Systems, 14 (2), pp. 50-62. doi:10.21511/bbs. 14 (2) 2019.05

- Horváth, Mérö, Zsámboki, 2002. “Tanulmányok a bankszektor tevékenységének prociklikusságáról”,

- MNB Mühelytanulmányok, http://mek.oszk.hu/01500/01567/01567.pdf

- IMF, 2017. "Ensuring Financial Stability in Countries with Islamic Banking. Executive Summary", https://www.imf.org/en/Publications/Policy-Papers/Issues/2017/02/21/PP-Ensuring-Financial-Stability-inCountries-with-Islamic-Banking.

- ICD-REFINITIV Islamic Finance Development Progress Report 2020 \#IFDI2020,

- $\quad$ https://icd-ps.org/uploads/files/ICD-Refinitiv\%20IFDI\%20Report\%2020201607502893_5274.pdf

- ISLAMIC FINANCIAL SERVICES BOARD (2017): ISLAMIC FINANCIAL SERVICES INDUSTRY STABILITY REPORT 2017,

- $\quad$ http://www.ifsb.org/docs/IFSB\%20IFSI\%20Stability\%20Report\%202017.pdf.

- Karapinar, Dogan, 2015. "An Analysis on the Performance of the Participation Banks in Turkey", Accounting and Finance Research, 4(2), 24-33.,

- $\quad$ http://www.scieduca/journal/index.php/afr/article/view/6479/3895

- Kettani, 2014. The World Muslim Population, History \& Prospect. Singapore Research Publishing Services.

- Lietaer, Schneider-Arnsperger, Goerner, 2012. Money and sustainability: the missing link. Triarchy Press. pp. 9.

- Lipka, 2017. "Muslims and Islam: Key findings in the U.S. and around the world", Pew Research Center 
- Masood, Ghauri, Aktan, 2016. "Predicting Islamic banks performance through CAMELS rating model", Banks and Bank Systems, 11(3), 37-43 doi:10.21511/bbs.11(3).2016.04

- Norrestad, 2021. “Assets of financial institutions worldwide 2002-2019”, Statista, https://www.statista.com/statistics/421060/global-financial-institutions-assets/

- Desilver, Masci, 2017. "World's Muslim population more widespread than you might think" Pew Research Center. January 31. 2017. http://www.pewresearch.org/fact-tank/2017/01/31/worlds-muslim-populationmore-widespread-than-you-might-think/

- Said, Ali, 2016. "An analysis on the factors affecting profitability level of Sharia banking in Indonesia", Banks and Bank Systems, 11(3), 28-36. doi:10.21511/bbs.11(3).2016.03

- Strüning, 2011. ”Muslimische Bevölkerungsentwicklung 1990-2030”, Citizen Times, (1 (2011): http://www.citizentimes.eu/2011/02/01/muslimische-bevoelkerungsentwicklung-1990-2030/.

- Tabash, 2017. "Critical challenges affecting Islamic banking growth in India us in Analytical Hierarchy Process (AHP)", Banks and Bank Systems, 12(3), 27-34. doi:10.21511/bbs.12(3).2017.02

- Tabash, Dankhar, 2014. "The Impact of Global Financial Crisis on the Stability of Islamic Banks: An Empirical Evidence”, Journal of Islamic Banking and Finance, Vo.2, No 1, pp. 367-388

- Tálos, Bánkuti, Varga, 2016. "The Analysis of the Turkish Islamic Banking System Between 2005 and 2014", In: International Conference on Eurasian Economies 2016. Eds. Selahattin Sar1, Alp H Gencer, İlyas Sözen, Kaposvár, pp. 116-127.

- $\quad$ THE IFSB COMPILATION GUIDE ON PRUDENTIAL AND STRUCTURAL ISLAMIC FINANCIAL INDICATORS (PSIFIs) Guidance on Compilation and Dissemination of Prudential and Structural Islamic Financial Indicators for Institutions offering Islamic Financial Services (IIFS). Published by: Islamic Financial Services Board, Kuala Lumpur, Malaysia, December 2019. pp. 34. ISBN: 978-967-5687-71-6

- Varga, 2012. “Az iszlám bankrendszer szerepe a pénzügyi stabilitás helyreállításában”, A virtuális intézet Közép-Európa kutatására közleményei 4: (1 (No.7)) pp. 121-132.

- Varga, Tálos, 2016. "The empirical analysis of the impact of the economic crisis on Turkish Islamic banks using the CAMEL method", Regional and Business Studies, 8(1), 77-87.

- Database of the Islamic Finance Sercive Board (ifsb): https://www.ifsb.org/

- Downloaded 10.06.2021.

- World Population Review: Muslim population data in 2021.

- https://worldpopulationreview.com/country-rankings/muslim-population-by-country

- Downloaded 10.06.2021.

- Worldometer, World Population by Religion 2021 https:/www.worldometers.info/world-population/

- Downloaded 10.06.2021.

- World Population Review https://worldpopulationreview.com/country-rankings/muslim-population-bycountry Downloaded 10.06.2021. 